\title{
Acute myasthenic syndrome following coral snake envenomation in the Caribbean: a harbinger for admission to the intensive care unit
}

\author{
Narine Mack, ${ }^{1}$ Antonio Jose Reyes, ${ }^{2}$ Kanterpersad Ramcharan (D) , \\ Stanley Lawrence Giddings ${ }^{4}$
}

${ }^{1}$ Medicine, San Fernando General Hospital, San Fernando, Trinidad and Tobago ${ }^{2}$ Medicine, Neurology Unit, San Fernando Teaching Hospital, San Fernando, Trinidad and Tobago ${ }^{3}$ Medicine, SurgiMed Clinic, San Fernando, Trinidad and Tobago ${ }^{4}$ Medicine, University of the West Indies at Saint Augustine, Saint Augustine, TunapunaPiarco, Trinidad and Tobago

Correspondence to Dr Kanterpersad Ramcharan; kramcharan79@yahoo.com

Accepted 13 March 2021

Check for updates

(c) BMJ Publishing Group Limited 2021. No commercial re-use. See rights and permissions. Published by BMJ.

To cite: Mack N, Reyes AJ, Ramcharan $\mathrm{K}$, et al. BMJ

Case Rep 2021:14:e241991. doi:10.1136/bcr-2021-

241991

\section{DESCRIPTION}

A 25 -year-old Afro-Caribbean woman was bitten by a snake in her right inner thigh while in a forest reserve in Trinidad and Tobago. As an ardent nature lover and animal rights activist, she had entered the rainforest with companions to release a wounded owl that had been rehabilitated. The snake was photographed by digital phones and later identified by a toxicologist as Micrurus lemniscatus, a coral snake species (figure 1A). The patient experienced local minor bleeding, followed 5 min later by regional swelling, pain and paraesthesia radiating to her upper thigh. She arrived at our tertiary care hospital 4 hours later. She had a history of allergic reactions to insect bites manifesting as local swelling, but no history of consumption of medications, recreational drugs, alcohol or tobacco. On admission, vital signs were normal. Neurological examination demonstrated bilateral palpebral ptosis (figure 1B), slurred speech, dysarthria, dysphagia, sialorrhoea and flaccid quadriparesis (grade 4/5). The deep tendon reflexes were preserved with no sensory abnormalities. The right inner thigh puncture is shown in figure 1C. The rest of the physical examination was normal. Her course in the hospital is shown in table 1.

Laboratory studies revealed normal full blood count, erythrocyte sedimentation rate, $\mathrm{C}$ reactive protein, coagulation, and renal and liver function tests. Serum calcium, phosphorous, magnesium, creatine kinase and amylase were also normal. Arterial blood gas remained normal during hospitalisation. Chest X-ray, ECG and echocardiogram were normal. An ultrasound examination of the right leg was normal. Electromyography and edrophonium test were not performed.

Diagnosed with progressive descending myasthenic syndrome of coral snake envenomation, we administered $80 \mathrm{~mL}$ of monovalent equine lyophilised coral antivenom intravenously with no adverse reactions or significant improvement. Atropine $0.6 \mathrm{mg}$ followed by neostigmine $1.5 \mathrm{mg}$ were given intravenously stat. Half an hour later, atropine $0.6 \mathrm{mg}$ followed by neostigmine $0.5 \mathrm{mg}$ were given intravenously stat again. Improvement in single breath count from 12 to 35 , muscle strength and sialorrhoea by more than $75 \%$, and ptosis in more than $25 \%$ in 1 hour were documented. No further administration of atropine-neostigmine was necessary in our patient due to appropriate and significant response thereafter. When the symptoms are not completely resolved, five additional doses of atropine-neostigmine $(0.6 \mathrm{mg} / 0.5 \mathrm{mg})$ should be given every half-hourly intravenously and then 2-12 hourly according to recovery. For severe cases, intravenous infusion of neostigmine at $12 \mu \mathrm{g} /$ $\mathrm{kg}$ /hour can be administered. ${ }^{1-3}$ Respiratory distress was resolved, and oxygen therapy and nebulisations were discontinued. The patient recovered and was discharged from hospital 5 days from admission.

Neostigmine is a reversible acetylcholinesterase inhibitor that restores neuromuscular transmission by increasing concentrations of acetylcholine at the neuromuscular junction, counteracting postsynaptic blockade at the nicotinic receptors. Neostigmine increases bronchial, gastric, sweat gland and salivary secretions at the muscarinic receptors. Atropine is an anticholinergic agent that inhibits smooth muscle and glands which are innervated by postganglionic cholinergic nerves, and is administered together with neostigmine most commonly to reduce the unwanted muscarinic effects of neostigmine by preventing excessive secretions. ${ }^{3}$

Coral snake venom contains $\alpha$-neurotoxins of the three-finger (3FTx) protein superfamily that cause muscle weakness by competitive inhibition of the nicotinic acetylcholine receptors at the

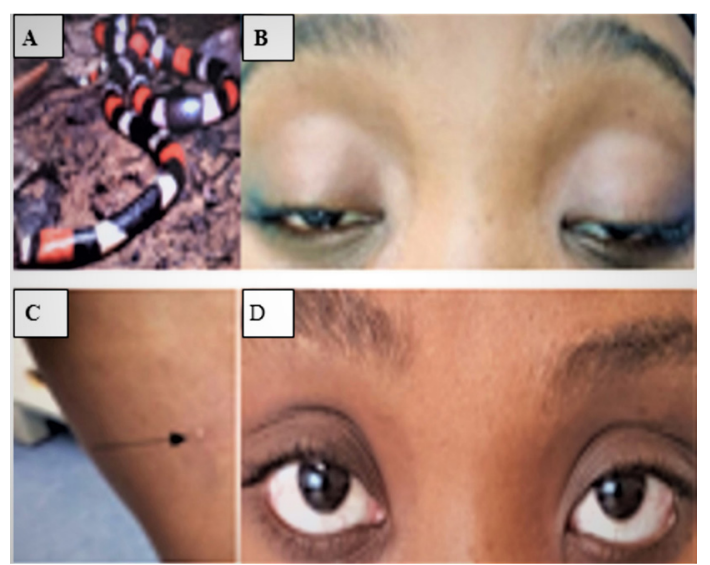

Figure 1 Images of (A) Micrurus lemniscatus and the patient showing (B) bilateral palpebral ptosis and (C) a small puncture mark in the right inner thigh (black arrow) caused by the snake bite. The patient experienced full recovery of the ptosis 10 days after treatment with neostigmine (D). 
Table 1 Clinical manifestations of envenomation by Micrurus lemniscatus in a 25-year-old Caribbean woman

Phase 1: initial manifestations, duration and treatment

Onset: between 5 and 60 min after the accident: local small bleeding, mild local pain and paraesthesia, and radiation of pain and local myalgia. Transferred to the nearest hospital.
Phase 2: neurological symptoms and signs before treatment, duration and treatment
Phase 3: neurological symptoms and signs afte treatment, duration and treatment

Onset: 1 hour after the bite, the patient showed bilateral $6-18$ hours after the bite, antivenom was given (1 vial palpebral ptosis, diplopia and dysarthria. Snake identification, toxicological centre contacted, antivenom requested and toxicologist informed. 2 hours after the bite, she experienced dysphonia, difficulty walking and decreased strength in the upper limbs, generalised myalgia and muscle tremors, and headache and dizziness.

Rest with immobilisation of the patient, local cleansing and antibiotic therapy (ceftriaxone $1 \mathrm{~g}$ intravenously daily) were instituted. A local incision with suction was out of therapeutic range ( $90 \mathrm{~min}$ post bite). Tetanus toxoid $0.5 \mathrm{~mL}$ was also given intramuscularly. Acetaminophen $1 \mathrm{~g}$ intravenously three times daily was given.

3-6hours after the bite, the sensorium was clear and the cranial and peripheral nerve functions were intact. However, there was severe difficulty speaking, dysphagia and profuse sialorrhoea. She developed mild shortness of breath. Oxygen therapy was given at $8 \mathrm{~L} / \mathrm{min}$ via a face mask.

The patient was put on NPO and a nasogastric tube was inserted. Nebulisations every 6 hours with epinephrine $5 \mathrm{mg}$ were given. Pantoprazole $40 \mathrm{mg}$ intravenously daily was given. $2 \mathrm{~L}$ of dextro-saline intravenous fluid was given daily for 2 days.

Transferred to the ICU for close neurological and respiratory monitoring, possible intubation and ventilatory support. Constant mouth suctioning of secretions was instituted. ABG done was normal. A skin test for sensitivity to coral snake antivenin (Laboratorios Probiol, Colombia) was negative. This antivenom was manufactured using Micrurus mipartitus venom. One vial of this antivenom should neutralise at least $1 \mu \mathrm{g}$ of the coral snake venom.

$A B G$, arterial blood gas; ICU, intensive care unit; NPO, nothing by mouth; NSG, nasogastric.

neuromuscular junction. Phospholipase A2 may cause myotoxicity and rhabdomyolysis. ${ }^{1-3}$

Hypersalivation from envenomation by coral snakes is uncommon. In 2006 Bucaretchi et $a l^{3}$ reported 1 case of moderate hypersalivation out of 11 (9.09\%) cases of envenomation with Micrurus species in Brazil. The concomitant manifestation of excessive salivation and neuromuscular features in that patient was not described. The first line of therapy for the neuromuscular blockade manifestations of neurotoxic snake

\section{Learning points}

- Acute myasthenic syndrome has been reported as a result of envenomation caused by the Elapidae (coral and cobra snakes) and viper snakes (Viper berus) families, and even from the poisonous sea snakes of the warm waters of the Indian and Pacific Oceans.

- Progressive myasthenic syndrome associated with snake envenomation is an early warning sign of impending respiratory paralysis and can respond to the specific antivenom and/or atropine-neostigmine therapy.

- Neuromuscular manifestations of snake envenomation can include myokymia, myoclonus, myospasm, myositis and myasthenic syndrome. envenomation is the specific snake antivenom. The administration of the combination of atropine-neostigmine is indicated when the antivenom is unavailable, if there is a delay in obtaining a sufficient amount, or in patients given the highest recommended doses of antivenom without improvement in paralysis or with delayed recovery. The glycopyrrolateneostigmine combination can also be used with success. ${ }^{1-3}$

M. lemniscatus is a highly venomous coral snake indigenous to the forests of Brazil, Bolivia, Colombia, Venezuela, Ecuador, Guyana, French Guiana, Suriname, Argentina, Paraguay, Peru and Trinidad and Tobago. ${ }^{1-3}$ M. lemniscatus characteristically has bright, bold-coloured rings, triad of black bands, small head, and a blunt and rounded snout (figure 1A).

This is the first published case from the Caribbean of acute myasthenic syndrome following coral snake envenomation causing respiratory paralysis. Timely intervention prevented death and disability. ${ }^{3}$ Snake bite is a neglected public health issue in the world, and education, improvement in healthcare and ongoing research are all essential. ${ }^{1-3}$

Correction notice This article has been corrected since it was published Online First. The value of "Tetanus toxoid" has been corrected from " $5 \mathrm{~mL}$ " to " $0.5 \mathrm{~mL}$ " in table 1.

Acknowledgements We wish to thank the patient for consenting to this case report and the many medical personnel who assisted in the care of this patient. 
Contributors NM and AJR conceived, planned and drafted the initial manuscript. AJR, NM, KR and SG worked on planning, data acquisition and interpretation. Subsequent revisions for intellectual content were also performed by NM, AJR, KR and SG.

Funding The authors have not declared a specific grant for this research from any funding agency in the public, commercial or not-for-profit sectors.

Competing interests None declared.

Patient consent for publication Obtained.

Provenance and peer review Not commissioned; externally peer reviewed.
ORCID iD

Kanterpersad Ramcharan http://orcid.org/0000-0003-2937-6362

\section{REFERENCES}

1 Mohan G, Singh A, Singh T. Guidelines for the management of snakebites. Curr Trends Diagn Treat 2018;2:102-8 https://www.ctdt.co.in/doi/pdf/

2 Bucaretchi F, Capitani EMD, Vieira RJ, et al. Coral snake bites (Micrurus spp.) in Brazil: a review of literature reports. Clin Toxicol 2016;54:222-34.

3 Bucaretchi F, Hyslop S, Vieira RJ, et al. Bites by coral snakes (Micrurus spp.) in Campinas, state of São Paulo, southeastern Brazil. Revista do Instituto de Medicina Tropical de São Paulo 2006;48:141-5. On-line version ISSN 1678-9946.

Copyright 2021 BMJ Publishing Group. All rights reserved. For permission to reuse any of this content visit

https://www.bmj.com/company/products-services/rights-and-licensing/permissions/

BMJ Case Report Fellows may re-use this article for personal use and teaching without any further permission.

Become a Fellow of BMJ Case Reports today and you can:

- Submit as many cases as you like

- Enjoy fast sympathetic peer review and rapid publication of accepted articles

- Access all the published articles

Re-use any of the published material for personal use and teaching without further permission

\section{Customer Service}

If you have any further queries about your subscription, please contact our customer services team on +44 (0) 2071111105 or via email at support@bmj.com.

Visit casereports.bmj.com for more articles like this and to become a Fellow 